\title{
Safety Evaluation, Biogenic Amine Formation, and Enzymatic Activity Profiles of Autochthonous Enterocin-Producing Greek Cheese Isolates of the Enterococcus faecium/durans Group
}

\author{
Charikleia Tsanasidou ${ }^{1}$, Stamatia Asimakoula ${ }^{2}$, Nikoletta Sameli ${ }^{1}$, Christos Fanitsios ${ }^{2} \mathbb{D}$, Elpiniki Vandera ${ }^{2}$, \\ Loulouda Bosnea ${ }^{1}{ }^{(\mathbb{D}}$, Anna-Irini Koukkou ${ }^{2}$ and John Samelis ${ }^{1, *(D)}$ \\ 1 Dairy Research Department, General Directorate of Agricultural Research, Hellenic Agricultural \\ Organization 'DIMITRA', Katsikas, 45221 Ioannina, Greece; xaroulatsan@gmail.com (C.T.); \\ nikol.sameli@gmail.com (N.S.); louloudaBosnea@gmail.com (L.B.) \\ 2 Laboratory of Biochemistry, Department of Chemistry, University of Ioannina, 45110 Ioannina, Greece; \\ s.asimakoula@uoi.gr (S.A.); chris.fanitsios@gmail.com (C.F.); evandera@uoi.gr (E.V.); \\ akukku@uoi.gr (A.-I.K.) \\ * Correspondence: jsam@otenet.gr; Tel.: +30-265-109-4789
}

check for updates

Citation: Tsanasidou, C.;

Asimakoula, S.; Sameli, N.; Fanitsios, C.; Vandera, E.; Bosnea, L.; Koukkou, A.-I.; Samelis, J. Safety Evaluation, Biogenic Amine Formation, and Enzymatic Activity Profiles of

Autochthonous Enterocin-Producing Greek Cheese Isolates of the Enterococcus faecium/durans Group. Microorganisms 2021, 9, 777. https://doi.org/10.3390/ microorganisms 9040777

Academic Editor: Wilhelm Holzapfel

Received: 9 March 2021

Accepted: 6 April 2021

Published: 8 April 2021

Publisher's Note: MDPI stays neutral with regard to jurisdictional claims in published maps and institutional affiliations.

Copyright: (C) 2021 by the authors Licensee MDPI, Basel, Switzerland. This article is an open access article distributed under the terms and conditions of the Creative Commons Attribution (CC BY) license (https:// creativecommons.org/licenses/by/ $4.0 /)$.

\begin{abstract}
Autochthonous single (Ent+) or multiple (m-Ent+) enterocin-producing strains of dairy enterococci show promise for use as bioprotective adjunct cultures in traditional cheese technologies, provided they possess no pathogenic traits. This study evaluated safety, decarboxylase activity, and enzymatic (API ZYM) activity profiles of nine Ent+ or m-Ent+ Greek cheese isolates previously assigned to four distinct E. faecium (represented by the isolates KE64 (entA), GL31 (entA), KE82 (entA-entB-entP) and KE77 (entA-entB-entP-bac31)) and two E. durans (represented by the isolates KE100 (entP) and KE108 (entP-bac31-cyl)) strain genotypes. No strain was $\beta$-hemolytic or harbored van $\mathrm{A}$ and $v a n \mathrm{~B}$ or the virulence genes $a g g$, ace, espA, IS16, hyl, or gelE. All strains were of moderate to high sensitivity to ampicillin, ciprofloxacin, chloramphenicol, erythromycin, gentamicin, penicillin, tetracycline, and vancomycin, except for the E. faecium KE64 and KE82 strains, which were resistant to erythromycin and penicillin. All cheese strains showed moderate to strong esterase-lipase and aminopeptidase activities and formed tyramine, but none formed histamine in vitro. In conclusion, all Ent+ or m-Ent+ strain genotypes of the E. faecium/durans group, except for the cyl-positive E. durans KE108, were safe for use as adjunct cultures in traditional Greek cheeses. Further in situ biotechnological evaluations of the strains in real cheese-making trials are required.
\end{abstract}

Keywords: Enterococcus faecium; E. durans; enterocins A, B, P; virulence genes; antibiotic resistance; biogenic amines; cheese adjuncts; Graviera; Galotyri

\section{Introduction}

Autochthonous dairy enterococci are strongly associated with traditional cheeses of the Mediterranean area [1-3]. Their levels range from $10^{4}$ to $10^{6} \mathrm{CFU} / \mathrm{g}$ in the fresh cheese curds and from $10^{5}$ to $10^{8} \mathrm{CFU} / \mathrm{g}$ in the resultant ripened cheeses, depending on the cheese type, whether the milk is processed raw, thermized, or pasteurized and on the type and activity of starter lactic acid bacteria (LAB) culture added to the milk [1,3,4]. Particularly in commercial starter culture (CSC)-free, traditional Greek hard and semi-hard cheeses $(\mathrm{pH}>5.0-5.7)$ produced from raw, thermized, or open-batch pasteurized milk, members of the E. faecium/durans and E. faecalis groups, are naturally selected to prevail [1,3,4]. Their prevalent growth in the fresh curds, and quite often during ripening of artisan Greek hard cheeses, has been attributed to the fact that enterococci are more tolerant to milk thermization and pasteurization than other raw milk LAB biota [5] and also have a broader growth temperature range $\left(4-45^{\circ} \mathrm{C}\right)$, with an optimum at $37^{\circ} \mathrm{C}[6]$. Growth of enterococci is more restricted in traditional Greek fresh or ripened acid-curd cheeses ( $\mathrm{pH} 3.8-4.7)[3,7]$ 
and soft white cheeses ripened in brine, such as Protected Designation of Origin (PDO) Feta cheese (ca. pH 4.5) [3], because they are sensitive to (lactic) acid. In general, beneficial dairy enterococci contribute to the aroma and taste of mature traditional cheeses, mainly by their in situ proteolytic activities [2,8,9]. In addition, numerous Enterococcus strains of (dairy) food origin boast production of a heterogeneous group of ribosomally synthesized antimicrobial peptides or proteins, termed enterocins, contributing to inhibit growth of several pathogenic and spoilage bacteria in situ in cheese [1,2,10]. Moreover, several single (Ent+) or multiple (m-Ent+) enterocin-producing dairy Enterococcus strains possess various probiotic properties [11]. Thus, these strains may offer health benefits and are required for developing novel functional (dairy) foods, such as probiotic cheeses [8,11,12].

On the other hand, there are still reasonable concerns and continuing scientific controversy regarding the safety risks associated with the natural prevalence and commercial application of enterococci in fresh or fermented (dairy) foods $[1,8,12,13]$. Overall, the genus Enterococcus includes opportunistic human pathogenic species or strains, many of which are $\beta$-hemolytic and/or multi-drug resistant clinical bacteria that possess and express virulence genes in vivo and can also transfer antibiotic resistance genes to $L A B$ and other beneficial food bacteria in situ [12-14]. Moreover, enterococci are able to grow at alkaline $\mathrm{pH}$ and produce high levels of biogenic amines by decarboxylating the amino acids present in (dairy) foods $[8,15]$. Hence, the use of Enterococcus spp. as commercial adjunct cultures in the food (dairy) industry is still prohibited because the genus has neither a generally regarded as safe (GRAS) status nor has it been included in the qualified presumption of safety (QPS) list [8]. Only certain E. faecium and E. faecalis strains have so far been permitted for use in dairy foods as individual co-starter cultures or have an approval as probiotic food supplements $[2,8,11,12]$. Nonetheless, an increasing number of recent polyphasic cheese ecology studies, including biotechnological and safety evaluations of numerous autochthonous harmless Enterococcus spp. isolates, have weakened safety concerns associated with the natural prevalence of dairy enterococci in artisan Mediterranean and Western Balkan cheese products [16-20].

Recently, we confirmed that CSC-free, naturally ripened traditional Greek Graviera cheeses represented a specific food ecological niche dominated $(79 \%)$ by diverse strain genotypes of the E. faecium/durans genomic group; $17 \%$ of those isolates exhibited Ent+ antilisterial activity in vitro [4]. The isolation frequency of $E$. faecalis from those Graviera cheeses was 3\% only [4]. Conversely, E. faecalis was more prevalent in artisan Galotyri PDO acid-curd cheeses from the Epirus market [7]. Eventually, 15 selected Ent+ Enterococcus isolates from Graviera and Galotyri cheeses were genotyped, and their structural enterocin gene profiles and mode of antilisterial activity were determined [6]. Most Ent+ E. faecalis isolates from Galotyri cheese harbored the cytolysin $\left(c y l L_{L}\right)$ gene [21], while one E. faecalis strain genotype was strongly $\beta$-hemolytic [6]. Thus, regardless of their strong antilisterial activity, E. faecalis isolates from Galotyri cheese were a priori excluded from (dairy) food applications [6]. Conversely, none of the Ent+ E. faecium and E. durans Greek cheese isolates were $\beta$-hemolytic. Five of them possessed only ent $\mathrm{A}$ or entP genes, while three E. faecium and one E. durans isolates were m-Ent+ gene possessors [6]. The present is a follow-up of the Vandera et al. [6] study, aiming to evaluate whether the above promising antilisterial strains of the E. faecium/durans genomic group are completely harmless and technologically suitable to be applied as co-starter or protective adjunct cultures in traditional Greek cheese technologies.

\section{Materials and Methods}

\subsection{LAB Strains and Culture Conditions}

Nine autochthonous Ent+ or m-Ent+ isolates of the E. faecium/durans group from artisan Greek Graviera and Galotyri PDO cheeses were selected for this study. Their designation, species identity, structural enterocin gene profiles, and mode of antilisterial activity data, adapted from previous studies, are summarized in Table 1. Briefly, the nine antilisterial cheese isolates belonged to four (EF1-EF4) and two (ED1,ED2) distinct strain 
genotypes of E. faecium and E. durans, respectively (Table 1). Their Random Amplified Polymorphic DNA (RAPD)-based genotyping was consistent with their biotyping at the strain level, except for E. faecium KE82 and KE118 isolates, which were biochemically distinct strains despite the fact that they shared their m-Ent+ (entA-entB-entP) and RAPD plasmid profiles (Table 1).

Six additional LAB strains were used as controls in the present bioassays (Table 1). In specific, E. faecalis ATCC ${ }^{\circledR} 29212^{\mathrm{TM}}$, a reference strain that possesses the gelE and ace virulence genes [22,23], and E. faecium 315VR, a vanA-positive isolate from a patient at the University Hospital of Ioannina, kindly provided by the Microbiology Laboratory of Medical Department, University of Ioannina, served as controls for the virulence gene detection and antibiotic susceptibility assays. Additional details on the origin, isolation, and primary properties of the Ent-negative E. faecium KE85, S. thermophilus CSL-ST1, Lc. lactis subsp. cremoris M78, and Lactiplantibacillus (formerly Lactobacillus) plantarum $\mathrm{H} 25$ starter or adjunct control strains are provided in the respective references in Table 1.

All LAB strains were incubated at $30{ }^{\circ} \mathrm{C}$ for $24 \mathrm{~h}$ in MRS broth (Neogen Culture Media, LAB094, Heywood, UK) for two sequent transfers before use, except for $S$. thermophilus ST1, which was cultivated twice in M17 broth (Merck, Darmstadt, Germany) at $37^{\circ} \mathrm{C}$ [24].

\subsection{Hemolytic Activity}

All LAB isolates were tested comparatively for hemolytic activity on ready-to-use $5 \%$ sheep blood agar plates (Bioprepare, Attiki, Greece), incubated aerobically at $37{ }^{\circ} \mathrm{C}$ for 48 to $72 \mathrm{~h}[6,19,20]$. One single batch of blood agar plates was used under identical experimental conditions to ensure uniformity of the results. The control starter strains S. thermophilus ST1, Lc. lactis subsp. cremoris M78, and Lb. plantarum H25 were expected to display a $\gamma$-hemolytic (negative) reaction. The virulent E. faecalis ATCC 29212 and the clinical E. faecium 315VR strains were evaluated for their potent $\beta$-hemolytic activity.

\subsection{Antibiotic Susceptibility}

Antibiotic susceptibility was tested by the Kirby-Bauer disk diffusion method [25]. Ready-to-use antibiotic disks were purchased from BioMaxima SA (Lublin, Poland). All LAB strains were screened for resistance to eight common antibiotics amongst those specified by the Clinical and Laboratory Standards Institute (CLSI) [26] for enterococci ( $\mu$ g per disk): ampicillin (AMP; 10), chloramphenicol (CHL; 30), ciprofloxacin (CIP; 5), erythromycin (ERY; 15), gentamicin (GEN; 10), penicillin G (PEN; 10 units per disk), tetracycline (TET; 30), and vancomycin (VAN; 30) as follows: $100 \mu \mathrm{L}$ of fresh (24-h) M17 broth cultures of each strain were spread with a sterile glass rod on two individual M17 agar plates, which were left to absorb for 5 to $10 \mathrm{~min}$. Afterward, 3-4 disks with different antibiotics were placed over the LAB cell lawn in each plate. The net diameter of the inhibition zones formed around each antibiotic disk was measured with a micrometer (model D15, Mitutoyo, Kanagawa, Japan) after overnight incubation of the M17 agar plates at $37^{\circ} \mathrm{C}$ for all strains. To account for potential LAB media effects on the size and clearness of the inhibition zones, the antibiotic susceptibility test was repeated, as above, by seeding the fresh cell culture lawns on MRS and BHI agar plates, comparatively to the M17 agar plates. The results were interpreted according to the breakpoints recommended by CLSI [26] for enterococci. E. faecium 315VR and E. faecalis ATCC 29212 (vancomycinsensitive) were used as positive and negative control strains, respectively. 
Table 1. Strains of lactic acid bacteria (LAB) used in this study.

\begin{tabular}{|c|c|c|c|c|c|c|c|}
\hline LAB Strain/Isolate Code & $\begin{array}{c}\text { Origin/Isolation } \\
\text { Source }\end{array}$ & $\begin{array}{c}\text { Strain } \\
\text { Genotype } \\
\text { RAPD-Based }\end{array}$ & $\begin{array}{c}\text { Strain } \\
\text { Biotype }\end{array}$ & $\begin{array}{c}\text { Structural } \\
\text { Bacteriocin } \\
\text { (Enterocin) Gene/s } \\
\text { Possessed }\end{array}$ & $\begin{array}{c}\text { Mode of } \\
\text { Bacteriocin Activity }\end{array}$ & References & $\begin{array}{c}\text { GenBank Accession } \\
\text { Number }\end{array}$ \\
\hline \multicolumn{8}{|l|}{$\begin{array}{l}\text { Autochthonous Enterococcus } \\
\text { strains under investigation }\end{array}$} \\
\hline Enterococcus faecium GL31 & Artisan Galotyri cheese PDO & EF1 & $1 \mathrm{C}$ & Ent+ (entA) & Bacteriostatic & {$[6,7]$} & MW709884 \\
\hline Enterococcus faecium KE64 & Graviera cheese (CSC-free) ${ }^{2}$ & EF2 & $1 \mathrm{~B}$ & Ent+ (entA) & Bactericidal & {$[4,6]$} & MW644963 \\
\hline Enterococcus faecium KE67 & Graviera cheese (CSC-free) & EF2 & $1 \mathrm{~B}$ & Ent $+($ ent $\mathrm{A})$ & Bactericidal & {$[4,6]$} & ND \\
\hline Enterococcus faecium KE82 & Graviera cheese (CSC-free) & EF4 & $1 \mathrm{D}$ & m-Ent+ (entA-B-P) & Bactericidal & {$[4,6]$} & MW644969 \\
\hline Enterococcus faecium KE118 & Graviera cheese (CSC-free) & EF4 & $1 \mathrm{~A}$ & m-Ent+ (entA-B-P) & Bacteriostatic & {$[4,6]$} & ND \\
\hline Enterococcus durans KE96 & Graviera cheese (CSC-free) & ED1 & $2 \mathrm{~A}$ & Ent+ (entP) & Bactericidal & {$[4,6]$} & ND \\
\hline Enterococcus durans KE100 & Graviera cheese (CSC-free) & ED1 & $2 \mathrm{~A}$ & Ent $+($ ent $\mathrm{P})$ & Bactericidal & {$[4,6]$} & MW644971 \\
\hline Enterococcus durans KE108 & Graviera cheese (CSC-free) & ED2 & $2 \mathrm{~B}$ & Ent+ (entP-bac31-cyl) & Bacteriostatic & {$[4,6]$} & MW644972 \\
\hline \multicolumn{8}{|l|}{ Reference/Control LAB strains } \\
\hline Enterococcus faecium KE85 & Graviera cheese (CSC-free) & Not tested & $1 \mathrm{D}$ & None (Ent-negative) & None & {$[4,6]$} & ND \\
\hline Enterococcus faecium 315VR & Clinical/Human/vanA+ & Unknown & NA & Not reported & Not reported & See text & Not reported \\
\hline $\begin{array}{c}\text { Enterococcus faecalis } \mathrm{ATCC}^{\circledR} \\
29212^{\mathrm{TM}}\end{array}$ & Virulent (gelE; ace) & Unknown & NA & Not reported & Not reported & {$[22,23]$} & ATCC strain \\
\hline Streptococcus thermophilus ST1 & CSC strain of natural origin & Not tested & NA & None & None & [24] & Not reported \\
\hline $\begin{array}{c}\text { Lactococcus lactis ssp. cremoris } \\
\text { M78 }\end{array}$ & Greek raw ewe's milk & M78 = M104 & NA & Nisin A (nisA) & Bactericidal & {$[5,27]$} & JX402634 \\
\hline Lactiplantibacillus plantarum $\mathrm{H} 25$ & Graviera cheese (with CSC) & Lb. plantarum & NA & None & None & {$[4,24]$} & ND \\
\hline
\end{tabular}

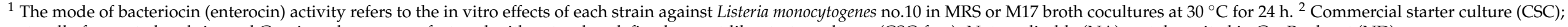
naturally fermented and ripened Graviera cheese manufactured with natural undefined yogurt-like starter cultures (CSC-free). Not applicable (NA); not deposited in GenBank yet (ND). 


\subsection{Detection of Vancomycin Resistance and Virulence Genes by PCR}

Bacterial genomic DNA (gDNA) from overnight cell cultures in MRS broth was extracted using cetyltrimethylammonium bromide (CTAB), according to William et al. [28] v. 3 and served as a template in PCR amplification reactions for the safety evaluation of the strains. All PCR reactions were performed in a DNA thermal cycler (G-STORM GS1, Labtech International Ltd., UK), using Taq Polymerase (KAPA Taq PCR Kit, Kapabiosystems Inc., Wilmington, MA, USA), according to the manufacturer's instructions. Agarose gel electrophoreses were carried out using standard methodology [29]. The primers used were synthesized by Eurofins Genomics Germany GmbH (Ebersberg, Germany).

The strains were assessed for the presence of vancomycin resistance genes (vanA, van $\mathrm{B})$ and six virulence genes ( $a g g$, ace, espA, IS16, hyl, and gelE) using specific primers (Table 2). Selection of the above virulence genes was based on the European Food Safety Authority (EFSA) guidance on the safety assessment of E. faecium in animal nutrition [30]. The presence of structural genes responsible for vancomycin resistance was investigated with a multiplex PCR reaction method, as described by Petrich et al. [31]. E. faecium 315VR was used as a positive control. The presence of virulence genes was investigated by PCR reactions for each target gene, as previously described [31-35]. E. faecalis ATCC 29212 served as a positive control strain for the virulence genes tested.

Table 2. List of primers used in the present study.

\begin{tabular}{|c|c|c|c|c|c|}
\hline Target Gene & Primer Pair & Primer Sequence $\left(5^{\prime}-3^{\prime}\right)$ & $\begin{array}{l}\text { Amplicon } \\
\text { Size (bp) }\end{array}$ & $\begin{array}{l}\text { Temp } \\
\left({ }^{\circ} \mathrm{C}\right)\end{array}$ & References \\
\hline \multicolumn{6}{|c|}{ Antibiotic resistance structural genes } \\
\hline $\operatorname{van} \mathrm{A}$ & vanA1 & GCTGCGATATTCAAAGCTCA & \multirow{2}{*}{545} & \multirow{2}{*}{50} & \multirow{2}{*}{ Petrich et al., [31] } \\
\hline (Vancomycin) & vanA2 & CAGTACAATGCGGCCGTTA & & & \\
\hline $\operatorname{van} \mathrm{B}$ & vanB1 & ATGGGAAGCCGATAGTCTC & \multirow{3}{*}{368} & \multirow{3}{*}{50} & \multirow{3}{*}{ Petrich et al., [31] } \\
\hline (Vancomycin) & vanB3 & GTTACGCCAAAGGACGAAC & & & \\
\hline & & Virulence determinants & & & \\
\hline$a g g$ & Agg-F & AAGAAAAAGAAGTAGACCAAC & \multirow{2}{*}{1553} & \multirow{2}{*}{53} & \multirow{2}{*}{ Espeche et al., [32] } \\
\hline (Aggregation protein) & Agg-R & AAACGGCAAGACAAGTAAATA & & & \\
\hline ace & Ace-F & CAGGCCAACATCAAGCAACA & \multirow[b]{2}{*}{125} & \multirow[b]{2}{*}{65} & \multirow{2}{*}{ Al-Talib et al., [33] } \\
\hline (Accessory colonization factor) & Ace-R & GCTTGCCTCGCCTTCTACAA & & & \\
\hline $\operatorname{esp} \mathrm{A}$ & EspA-F & TTTGGGGCAACTGGAATAGT & \multirow[b]{2}{*}{407} & \multirow[b]{2}{*}{60} & \multirow{2}{*}{ Al-Talib et al., [33] } \\
\hline (Enterococcal surface protein) & EspA-R & CCCAGCAAATAGTCCATCAT & & & \\
\hline IS16 & IS16-F & CATGTTCCACGAACCAGAG & \multirow[b]{2}{*}{547} & \multirow[b]{2}{*}{55} & \multirow{2}{*}{$\begin{array}{c}\text { Werner et al., [34] } \\
\text { EFSA [30] }\end{array}$} \\
\hline (Transposable element) & IS16-R & TCAAAAAGTGGGCTTGGC & & & \\
\hline hyl & HyI-F & ACAGAAGAGCTGCAGGAAATG & \multirow[b]{2}{*}{276} & \multirow[b]{2}{*}{58} & \multirow{2}{*}{$\begin{array}{c}\text { Vankerckhoven } \\
\text { et al., [35] }\end{array}$} \\
\hline (Hyaluronidase) & HyI-R & GACTGACGTCCAAGTTTCCAA & & & \\
\hline$g e l \mathrm{E}$ & GelE-F & CGAAGTTGGAAAAGGAGGC & \multirow[b]{2}{*}{372} & \multirow[b]{2}{*}{50} & \multirow{2}{*}{ Al-Talib et al., [33] } \\
\hline (Gelatinase) & GelE-R & GGTGAAGAAGTTACTCTGA & & & \\
\hline
\end{tabular}

\subsection{Detection of Biogenic Amine Formation}

The Ent+ or m-Ent+Enterococcus isolates were evaluated for their in vitro ability to produce the commonest biogenic amines (BAs) in cheese, histamine (HIS), and tyramine (TYR) by using the screening method of Bover-Cid and Holzapfel [36] without the previous activation step. Briefly, $100 \mu \mathrm{L}$ of fresh (24-h) MRS or M17 pure cultures of the strains were inoculated in $5-\mathrm{mL}$ portions of improved BA broth medium with $1 \%$ histidine or $1 \%$ tyrosine (Merck), adjusted to $\mathrm{pH} 5.4$ prior to autoclaving. Tubes with 5-mL portions of control (CN) BA broth, without histidine or tyrosine, were inoculated for comparison. All cultures were incubated at $37^{\circ} \mathrm{C}$ for $72 \mathrm{~h}$. Positive tubes showing BA (either HIS or TYR) production were recorded by the color change of the bromocresol indicator from yellowish to bright blue or purple. E. faecalis ATCC 29212, E. faecium 315VR, and the non-enterococcal LAB strains ST1, M78, and H25 (Table 1) were also tested as above. The in vitro formation of TYR and HIS in the pure BA broth cultures of most LAB strains was verified and quantified by HPLC after completion of the 72-h incubation period. 


\subsection{Determination of Biogenic Amine Formation by HPLC}

Determination by HPLC of the BAs in the LAB culture broth supernatants was carried out by acid extraction and derivatization using the method of Eerola et al. [37]. To account for the potential formation of HIS or TYR in the $\mathrm{CN}$ samples and evaluate the ability of the strains to form additional BAs, six BAs in total, namely cadaverine, histamine, putrescine, spermidine, tryptamine, tyramine, and 2-phenylethylamine, purchased from Sigma-Aldrich Chemie GmbH (Steinheim, Germany) or Acros Organics (Geel, Belgium), were analyzed by HPLC.

For sample preparation, the cell-free cultured $\left(37^{\circ} \mathrm{C} ; 72 \mathrm{~h}\right)$ filtrate supernatants of each LAB strain that originally contained $1 \%$ histidine or $1 \%$ tyrosine, respectively, were pooled, regardless of whether they were positive or negative. All respective $\mathrm{CN}$ culture supernatants stayed separate for HPLC analysis. Afterward, $4 \mathrm{~mL}$ of each LAB culture, together with $125 \mu \mathrm{L}$ of each BA stock solution, were adjusted to $25 \mathrm{~mL}$ with $\mathrm{HClO}_{4} 0.4 \mathrm{M}$. Following derivatization according to [37], the final sample mixture was diluted to $5 \mathrm{~mL}$ with acetonitrile (Carlo Ebra Reagents S.A.S, Val de Reuil, France), centrifuged at $2500 \mathrm{rpm}$ at $25^{\circ} \mathrm{C}$ for $5 \mathrm{~min}$, and $20 \mu \mathrm{L}$ of the supernatant was injected into the HPLC.

The BA derivatives $(20 \mu \mathrm{L})$ filtered through a $0.45-\mu \mathrm{m}$ filter were analyzed on a LC-20AT high-performance liquid chromatograph (Shimadzu, Tokyo, Japan) equipped with a thermo-stated auto-sampler (SIL-20A), a high pressure mixing binary pump (LC20AT), a column oven (CTO-20A), and a diode array detector (SPD-M20A). Separation of the derivatives was carried out on a Shim-pack GIST C18 column $(3 \mu \mathrm{m}, 100 \times 3 \mathrm{~mm}$ I.D, Shimazdu, Japan) equipped with a guard column. A gradient elution program with ammonium acetate (Carlo Erba) 0.1 M (A) and acetonitrile (B) was used. Gradient started at $50 \%$ and ended at $90 \%$ acetonitrile in $19 \mathrm{~min}$. The flow rate of the mobile phase was $0.9 \mathrm{~mL} / \mathrm{min}$, the column temperature was set at $40^{\circ} \mathrm{C}$, and the peaks were detected at $254 \mathrm{~nm}$. Identification of the BAs was based on their retention times. The lines of regression calculated were used to compute the amount of the analytes in the samples by interpolation, using as an internal standard, $1 \mathrm{mg} / \mathrm{mL}$ of 1,7-diaminoheptane (Sigma-Alrdich). The HPLC system was equilibrated for $10 \mathrm{~min}$ before the next analysis.

\subsection{Enzymatic Activity Profiles}

The enzymatic activity profiles of the Ent+ or m-Ent+Enterococcus and the control LAB strains (Table 1) were determined by the API ZYM method (BioMerieux, Marcy l' Etoile, Lyon, France) at $37^{\circ} \mathrm{C}$ for $4 \mathrm{~h}$, according to the manufacturer's instructions.

\section{Results}

\subsection{Safety Characteristics of the Ent+ or $m-E n t+E$. Faecium and E. Durans Cheese Isolates}

None of the cheese LAB isolates tested in this study were $\beta$-hemolytic. However, all nine Ent+ or m-Ent+ E. faecium or E. durans isolates and the Ent-negative KE85 strain showed $\alpha$-hemolysis manifested as a green discoloration around the streaked colony growth on 5\% sheep blood agar (Table 3). E. durans KE96 = KE100 showed the weakest $\alpha$-hemolytic reaction that might have been perceived as $\gamma$-hemolysis in the absence of the S. thermophilus ST1 and Lc. lactis M78 control strains, which clearly were $\gamma$-hemolytic (no color change). In contrast, $L b$. plantarum $\mathrm{H} 25$ displayed the strongest $\alpha$-hemolytic reaction. The two virulent Enterococcus control strains were $\beta$-hemolytic (Table 3).

All Ent+ or m-Ent+ E. faecium and E. durans cheese isolates were susceptible to ampicillin, chloramphenicol, tetracycline, and, most importantly, vancomycin. E. faecium KE85 was also susceptible to ampicillin, chloramphenicol, and vancomycin, but it was resistant to tetracycline (Table 3). Susceptibility of the isolates to the above four antibiotics was measured according to the disk-assay breakpoints recommended by CLSI [26] for enterococci and was in comparison to the corresponding susceptibilities of the van $\mathrm{A}+$ E. faecium $315 \mathrm{VR}$ positive control. Actually, this clinical strain, apart from being $\beta$-hemolytic, was found to be extremely (no inhibition zone) to highly multi-resistant $(<10 \mathrm{~mm})$ to seven antibiotics tested; it was susceptible to chloramphenicol only (Table 3). E. faecium KE64 = KE67, 
KE82, and KE85 strains were resistant to penicillin, whereas the remaining three E. faecium KE77, KE118, and GL31 strains and both strain genotypes of E. durans were susceptible to penicillin. Additionally, according to the CLSI protocol, all Enterococcus cheese isolates were resistant or of intermediate susceptibility to ciprofloxacin and erythromycin, despite being inhibited by the above antibiotics (11.0-20.9 $\mathrm{mm}$ ), and none were highly resistant (no inhibition zone), while the 315VR clinical strain was (Table 3).

Table 3. Hemolytic activity and antibiotic susceptibility of the Ent+ Greek cheese isolates of the E. faecium/durans group.

\begin{tabular}{|c|c|c|c|c|c|c|c|c|c|}
\hline \multirow[t]{2}{*}{ Strain (Isolate) } & \multirow{2}{*}{$\begin{array}{c}\text { Type of } \\
\text { Hemolytic } \\
\text { Activity }\end{array}$} & \multicolumn{8}{|c|}{ Antibiotic Tested ( $\mu \mathrm{g} / \mathrm{disc})$} \\
\hline & & $\begin{array}{c}\text { AMP } \\
10\end{array}$ & $\begin{array}{c}\text { CHL } \\
30\end{array}$ & $\begin{array}{c}\text { CIP } \\
5\end{array}$ & $\begin{array}{c}\text { ERY } \\
15\end{array}$ & $\begin{array}{c}\text { GEN } \\
10\end{array}$ & $\begin{array}{l}\text { PEN } \\
10 U\end{array}$ & $\begin{array}{c}\text { TET } \\
30\end{array}$ & $\begin{array}{c}\text { VAN } \\
30\end{array}$ \\
\hline \multicolumn{10}{|l|}{ Ent+ or $\mathrm{m}$-Ent+ isolates } \\
\hline E. faecium KE64 & $\alpha$ & $\begin{array}{c}S \\
(17.5)\end{array}$ & $\begin{array}{c}S \\
(23.9)\end{array}$ & $\begin{array}{c}\mathrm{I} \\
(18.0)\end{array}$ & $\begin{array}{c}\mathrm{R} \\
(12.1)\end{array}$ & $\begin{array}{c}S \\
(10.4)\end{array}$ & $\begin{array}{c}\mathrm{R} \\
(13.2)\end{array}$ & $\begin{array}{c}S \\
(27.5)\end{array}$ & $\begin{array}{c}S \\
(18.5)\end{array}$ \\
\hline E. faecium KE67 & $\alpha$ & $\begin{array}{c}\text { S } \\
(18.4)\end{array}$ & $\begin{array}{c}\mathrm{S} \\
(24.6)\end{array}$ & $\begin{array}{c}\text { I } \\
(16.5)\end{array}$ & $\begin{array}{c}\mathrm{R} \\
(11.7)\end{array}$ & $\begin{array}{c}S \\
(9.6)\end{array}$ & $\begin{array}{c}\mathrm{R} \\
(12.5)\end{array}$ & $\begin{array}{c}\mathrm{S} \\
(26.9)\end{array}$ & $\begin{array}{c}\mathrm{S} \\
(18.6)\end{array}$ \\
\hline E. faecium KE77 & $\alpha$ & $\begin{array}{c}\mathrm{S} \\
(26.4)\end{array}$ & $\begin{array}{c}\text { S } \\
(25.5)\end{array}$ & $\begin{array}{c}\text { I } \\
(18.2)\end{array}$ & $\begin{array}{c}\mathrm{I} \\
(18.5)\end{array}$ & $\begin{array}{c}\text { S } \\
(14.4)\end{array}$ & $\begin{array}{c}\mathrm{S} \\
(22.8)\end{array}$ & $\begin{array}{c}\mathrm{S} \\
(28.1)\end{array}$ & $\begin{array}{c}\mathrm{S} \\
(19.8)\end{array}$ \\
\hline E. faecium KE82 & $\alpha$ & $\begin{array}{c}\text { S } \\
(17.3)\end{array}$ & $\begin{array}{c}\mathrm{S} \\
(24.9)\end{array}$ & $\begin{array}{c}\mathrm{R} \\
(12.0)\end{array}$ & $\begin{array}{c}\mathrm{R} \\
(11.0)\end{array}$ & $\begin{array}{c}\text { S } \\
(11.3)\end{array}$ & $\begin{array}{c}\mathrm{R} \\
(11.3)\end{array}$ & $\begin{array}{c}\mathrm{S} \\
(28.3)\end{array}$ & $\begin{array}{c}\mathrm{S} \\
(19.4)\end{array}$ \\
\hline E. faecium KE118 & $\alpha$ & $\begin{array}{c}\mathrm{S} \\
(17.0)\end{array}$ & $\begin{array}{c}\mathrm{S} \\
(22.7)\end{array}$ & $\begin{array}{c}\mathrm{R} \\
(13.0)\end{array}$ & $\begin{array}{c}\mathrm{R} \\
(12.7)\end{array}$ & $\begin{array}{c}S \\
(11.6)\end{array}$ & $\begin{array}{c}\mathrm{S} \\
(14.5)\end{array}$ & $\begin{array}{c}\mathrm{S} \\
(25.9)\end{array}$ & $\begin{array}{c}\mathrm{S} \\
(18.6)\end{array}$ \\
\hline E. faecium GL31 & $\alpha$ & $\begin{array}{c}\text { S } \\
(23.6)\end{array}$ & $\begin{array}{c}\text { S } \\
(23.2)\end{array}$ & $\begin{array}{c}\mathrm{R} \\
(14.4)\end{array}$ & $\begin{array}{c}\mathrm{I} \\
(13.5)\end{array}$ & $\begin{array}{c}\text { S } \\
(11.8)\end{array}$ & $\begin{array}{c}\text { S } \\
(19.4)\end{array}$ & $\begin{array}{c}\text { S } \\
(25.3)\end{array}$ & $\begin{array}{c}\text { S } \\
(18.1)\end{array}$ \\
\hline E. durans KE96 & $\alpha / \gamma$ & $\begin{array}{c}S \\
(22.2)\end{array}$ & $\begin{array}{c}\mathrm{S} \\
(22.1)\end{array}$ & $\begin{array}{c}\text { I } \\
(18.5)\end{array}$ & $\begin{array}{c}\mathrm{I} \\
(21.6)\end{array}$ & $\begin{array}{c}\text { S } \\
(10.6)\end{array}$ & $\begin{array}{c}\mathrm{S} \\
(19.2)\end{array}$ & $\begin{array}{c}\mathrm{S} \\
(22.9)\end{array}$ & $\begin{array}{c}\mathrm{S} \\
(17.8)\end{array}$ \\
\hline E. durans KE100 & $\alpha / \gamma$ & $\begin{array}{c}S \\
(20.0)\end{array}$ & $\begin{array}{c}\mathrm{S} \\
(21.7)\end{array}$ & $\begin{array}{c}\text { I } \\
(20.4)\end{array}$ & $\begin{array}{c}\text { I } \\
(20.9)\end{array}$ & $\begin{array}{c}\text { S } \\
(10.7)\end{array}$ & $\begin{array}{c}\mathrm{S} \\
(17.1)\end{array}$ & $\begin{array}{c}S \\
(23.0)\end{array}$ & $\begin{array}{c}\mathrm{S} \\
(18.0)\end{array}$ \\
\hline E. durans KE108 & $\alpha$ & $\begin{array}{c}\mathrm{S} \\
(23.4)\end{array}$ & $\begin{array}{c}\text { S } \\
(26.9)\end{array}$ & $\begin{array}{c}\text { I } \\
(19.8)\end{array}$ & $\begin{array}{c}S \\
(24.0)\end{array}$ & $\begin{array}{c}S \\
(10.2)\end{array}$ & $\begin{array}{c}\text { S } \\
(19.3)\end{array}$ & $\begin{array}{c}S \\
(24.0)\end{array}$ & $\begin{array}{c}\mathrm{S} \\
(19.0)\end{array}$ \\
\hline $\begin{array}{l}\text { E. faecium KE85 } \\
\text { (Ent-/control) }\end{array}$ & $\alpha$ & $\begin{array}{c}S \\
(16.6)\end{array}$ & $\begin{array}{c}S \\
(26.3)\end{array}$ & $\begin{array}{c}\mathrm{R} \\
(12.8)\end{array}$ & $\begin{array}{c}\mathrm{I} \\
(17.4)\end{array}$ & $\begin{array}{c}S \\
(10.3)\end{array}$ & $\begin{array}{c}\mathrm{R} \\
(13.2)\end{array}$ & $\begin{array}{c}\mathrm{R} \\
(9.6)\end{array}$ & $\begin{array}{c}S \\
(21.4)\end{array}$ \\
\hline \multicolumn{10}{|l|}{ Virulent Enterococcus spp. } \\
\hline E. faecium 315VR (van $\mathrm{A}+)$ & $\beta$ & $\begin{array}{c}\mathrm{R} \\
(0.0)\end{array}$ & $\begin{array}{c}\text { S } \\
(25.6)\end{array}$ & $\begin{array}{c}\mathrm{R} \\
(0.0)\end{array}$ & $\begin{array}{c}\mathrm{R} \\
(0.0)\end{array}$ & $\begin{array}{c}\mathrm{R} \\
(0.0)\end{array}$ & $\begin{array}{c}\mathrm{R} \\
(0.0)\end{array}$ & $\begin{array}{c}\mathrm{R} \\
(9.5)\end{array}$ & $\begin{array}{c}\mathrm{R} \\
(9.5)\end{array}$ \\
\hline E. faecalis ATCC 29212 & $\beta$ & $\begin{array}{c}\mathrm{S} \\
(23.0)\end{array}$ & $\begin{array}{c}\mathrm{S} \\
(23.7)\end{array}$ & $\begin{array}{c}\text { I } \\
(18.3)\end{array}$ & $\begin{array}{c}\text { I } \\
(15.3)\end{array}$ & $\begin{array}{c}S \\
(7.6)\end{array}$ & $\begin{array}{c}\mathrm{S} \\
(20.2)\end{array}$ & $\begin{array}{c}\mathrm{I} \\
(16.6)\end{array}$ & $\begin{array}{c}\mathrm{I} \\
(15.6)\end{array}$ \\
\hline \multicolumn{10}{|l|}{ Starter LAB strains } \\
\hline S. thermophilus ST1 & $\gamma$ & $\begin{array}{c}\text { S } \\
(28.4)\end{array}$ & $\begin{array}{c}\text { S } \\
(27.2)\end{array}$ & $\begin{array}{c}\text { S } \\
(20.0)\end{array}$ & $\begin{array}{c}\text { S } \\
(27.3)\end{array}$ & NT & $\begin{array}{c}\text { S } \\
(17.3)\end{array}$ & $\begin{array}{c}\text { S } \\
(25.1)\end{array}$ & $\begin{array}{c}\text { S } \\
(19.9)\end{array}$ \\
\hline Lc. lactis ssp. cremoris M78 & $\gamma$ & $\begin{array}{c}\mathrm{S} \\
(23.2)\end{array}$ & $\begin{array}{c}\text { S } \\
(24.0)\end{array}$ & $\begin{array}{c}\mathrm{R} \\
(13.2)\end{array}$ & $\begin{array}{c}\mathrm{S} \\
(23.8)\end{array}$ & $\begin{array}{c}\mathrm{R} \\
(0.0)\end{array}$ & $\begin{array}{c}S \\
(14.2)\end{array}$ & $\begin{array}{c}R \\
(9.9)\end{array}$ & $\begin{array}{c}\mathrm{S} \\
(17.2)\end{array}$ \\
\hline Lb. plantarum $\mathrm{H} 25$ & $\alpha$ & $\begin{array}{c}S \\
(26.0)\end{array}$ & $\begin{array}{c}\mathrm{S} \\
(26.5)\end{array}$ & $\begin{array}{c}\mathrm{R} \\
(9.5)\end{array}$ & NT & $\begin{array}{c}\mathrm{R} \\
(0.0)\end{array}$ & $\begin{array}{c}S \\
(19.1)\end{array}$ & $\begin{array}{c}\mathrm{I} \\
(17.3)\end{array}$ & $\begin{array}{c}\mathrm{R} \\
(0.0)\end{array}$ \\
\hline
\end{tabular}

Ampicillin (AMP); chloramphenicol (CHL); ciprofloxacin (CIP); erythromycin (ERY); gentamicin (GEN); penicillin (PEN); tetracycline (TET); vancomycin (VAN). The numbers underneath the antibiotics indicate $\mu \mathrm{g}$ per disk or units per disk for penicillin.S, strain susceptible to the antibiotic tested; R, strain resistant to the antibiotic tested; I, the tested strain was of intermediate antibiotic susceptibility according to the Clinical and Laboratory Standards Institute (CLSI) breakpoints [26]; the numbers in parentheses indicate the size (in $\mathrm{mm}$ ) of the inhibition zone. NT, not tested.

Notably, the Ent+ or m-Ent+ E. durans strains were also more susceptible to ciprofloxacin, and mainly eryrthomycin, than the $\mathrm{m}$-Ent+ E. faecium KE82 and KE118 and the EntA+ E. faecium KE64 = KE67 strains (Table 3). Compared to E. faecium 315VR, all E. faecium and E. durans cheese isolates were susceptible to only $10 \mu \mathrm{g} /$ disk of gentamicin. Finally, S. thermophilus ST1 was susceptible to all antibiotics tested. Lc. lactis M78 was phenotypically resistant to ciprofloxacin, gentamicin, and tetracycline, and $L b$. plantarum $\mathrm{H} 25$ was phenotypically resistant to ciprofloxacin, gentamicin, and vancomycin (Table 3). 
None of the cheese starter or adjunct LAB strains evaluated in this study, including all nine Ent+ or m-Ent+ E. faecium and E. durans isolates, possessed any of the vanA, vanB, agg, ace, espA, IS16, hyl or gelE genes (Supplementary Figures S1-S3).

All E. faecium and E. durans cheese isolates were profoundly able to form tyramine in vitro; however, none formed histamine under the same culturing conditions (Table 4). Tyramine formation was confirmed by HPLC quantifications, which showed that the m-Ent+ (A-B-P) E. faecium KE82 was the highest tyramine-producer, whereas the EntA+ E. faecium GL31 was the lowest tyramine-producer. Overall, the E. durans strains formed less amounts of tyramine than the E. faecium strains in BA broth in vitro (Table 4).

None of the ST1, M78, or H25 non-enterococcal, starter, or adjunct LAB strains formed tyramine or histamine in vitro. Additionally, minor tyramine and histamine amounts were formed in four of the respective cultured BA control samples (KE77, KE108, M78, and H25) tested by HPLC (Table 4). Furthermore, minor to negligible amounts of additional BAs, mainly tryptamine and 2-phenylethylamine were detected in all HPLC-tested cultured BA samples of the LAB strains, irrespective of the presence of $1 \%$ tyrosine and $1 \%$ histidine as precursor amino acids (data not shown).

Table 4. Detection and HPLC-based quantification (mg/L) of histamine (HIS) and tyramine (TYR) formed in vitro by pure cultures of the Enterococcus cheese isolates in improved biogenic amine (BA) broth [36] after culturing at $37^{\circ} \mathrm{C}$ for $72 \mathrm{~h}^{1}$.

\begin{tabular}{|c|c|c|c|}
\hline Isolate/Strain & $\begin{array}{c}\text { BA Broth without } \\
\text { Amino ACIDS Added }\end{array}$ & $\begin{array}{c}\text { BA Broth with } \\
1 \% \text { Histidine Added }\end{array}$ & $\begin{array}{c}\text { BA Broth with } \\
\text { 1\% Tyrosine Added }\end{array}$ \\
\hline \multicolumn{4}{|l|}{ Ent + or $\mathrm{m}-\mathrm{En} \mathrm{t}+$ isolates } \\
\hline E. faecium KE64 & $-/ \mathrm{NT}$ & $-/ \mathrm{NT}$ & $++/ \mathrm{NT}$ \\
\hline E. faecium KE67 & $-/ \mathrm{NT}$ & $-/ \mathrm{NT}$ & $++/ \mathrm{NT}$ \\
\hline E. faecium KE77 & $(+) / 18.4 ; 35.3$ & $-/ 74.0$ & $++/ 1683.8$ \\
\hline E. faecium KE82 & $-/ \mathrm{NT}$ & -/traces & $++/ 2706.4$ \\
\hline E. faecium KE118 & $(+) / \mathrm{NT}$ & $-/ N T$ & $++/ \mathrm{NT}$ \\
\hline E. faecium GL31 & $(+) / \mathrm{NT}$ & $(+) / 16.0$ & $++/ 1247.3$ \\
\hline E. durans KE96 & $(+) / \mathrm{NT}$ & $(+) / 15.2$ & $++/ 1849.2$ \\
\hline E. durans KE100 & $(+) / \mathrm{NT}$ & $(+) / 15.3$ & $++/ 1631.6$ \\
\hline E. durans KE108 & $-/ 13.3 ; 7.3$ & $-/ 17.8$ & $++/ 2154.5$ \\
\hline $\begin{array}{c}\text { E. faecium KE85 } \\
\text { (Ent-/control) }\end{array}$ & - & $-/ 15.2$ & $++/ 2249.1$ \\
\hline \multicolumn{4}{|l|}{ Virulent Enterococcus spp. } \\
\hline E. faecium 315VR (vanA+) & $(+) / \mathrm{NT}$ & $-/ \mathrm{NT}$ & $+/ \mathrm{NT}$ \\
\hline E. faecalis ATCC 29212 & $-/ \mathrm{NT}$ & $-/ \mathrm{NT}$ & $+/ \mathrm{NT}$ \\
\hline \multicolumn{4}{|l|}{ Starter LAB strains } \\
\hline S. thermophilus ST1 & NG & NG & NG \\
\hline Lc. lactis ssp. cremoris M78 & $-/ 13.6 ; 31.6$ & $-/ 8.1$ & $-/ 53.8$ \\
\hline Lb. plantarum $\mathrm{H} 25$ & $-/ 18.1 ; 187.1$ & $-/ 17.0$ & $-/ 35.1$ \\
\hline
\end{tabular}

${ }^{1}$ Detection of HIS or TYR in BA broth by the indicator's color change is indicated with the symbols left to each slash; the values given right to each slash indicate the HIS or TYR concentration $(\mathrm{mg} / \mathrm{L})$ in the BA sample of each strain in the control BA samples (2nd column), the first concentration value refers to HIS and the second value to TYR; NT = the sample was not tested by HPLC.++ =strong positive reaction (bright dark blue to purple); $+=$ positive reaction (blue to light blue/grey color); $(+)=$ weak positive reaction manifested as browning-greenish of the BA medium;- =negative reaction (yellow to light green color); NG = no growth of the tested strain even in the control medium without added aminoacids.

\subsection{Species-Dependent Differences of the Cheese Isolates in Their Enzymatic Activity Profiles}

The API-ZYM activity profiles of the Ent+ or m-Ent+ cheese isolates are shown in Table 5, comparatively with the respective profiles of the control ST1, M78, H25, and KE85 strains. Major similarities, but also major species-dependent or strain-dependent differences, were observed. All Enterococcus isolates, including the Ent-negative KE85 control strain showed generally moderate alkaline phosphatase activity and moderate to high esterace (C4) and esterase-lipase (C8) activities, whereas no isolate showed lipase (C14) activity. Additionally, all Enterococcus isolates displayed acid phosphatase and napthol-ASBI-phosphohydrolase activities, except the Ent- KE85 control strain (Table 5). With regard to their proteolytic activities, all amino acid (i.e., leucine, valine, and cystine) arylamidase 
reactions were moderate to strong in all Ent+ or m-Ent+ cheese isolates. Again, the only exception was the Ent- KE85 control strain, which was positive with leucine but negative with valine and cystine (Table 5).

Prominent differences occurred in $\alpha$-chymotrypsin activity; they appeared to be species-dependent and secondarily strain-dependent. Indeed, both E. durans strain genotypes lacked $\alpha$-chymotrypsin activity. The m-Ent+ E. faecium KE118 strain lacked $\alpha$ chymotrypsin activity also. In contrast, the other m-Ent+ E. faecium strain KE82 that shared its structural entA-entB-entP gene and RAPD profiles with strain KE118 (Table 1) was strongly active for $\alpha$-chymotrypsin. This result confirmed that KE82 and KE118 are clearly different strain biotypes. The remaining E. faecium strains displayed weak $\alpha$-chymotrypsin activity, including the Ent-KE85 control strain, which, overall, possessed the poorest enzymatic activity profile (Table 5 ).

All enterococcal strains displayed negative glycolytic enzyme reactions, except the $\mathrm{m}$-Ent+ E. faecium KE77 strain, which showed weak $\alpha$-galactosidase and $\alpha$-glucosidase activities and the EntA+ E. faecium KE64 = KE67 strain genotype, which showed weak $\beta$-galactosidase activity (Table 5). The E. durans Graviera cheese isolates (KE96, KE100, and KE108) were negative for $\alpha$-galactosidase (Table 5). In summary, the API-ZYM profiles provided several enzymatic reactions for the differentiation of E. faecium and E. durans cheese isolates at both the species and strain level. Contrary to the E. faecium/durans group of cheese isolates, the starter and adjunct control (non-enterococcal) strains displayed strong $\alpha$-galactosidase (H25), $\beta$-galactosidase (ST1, H25), and $\alpha$-glucosidase (M78, H25) activities (Table 5). Clearly, the nonstarter Lb. plantarum $\mathrm{H} 25$ possessed the most and overall strongest enzymatic activities, followed by the indigenous nis A+ Lc. lactis subsp. cremoris M78 co-starter. Conversely, the primary starter S. thermophilus ST1 showed only strong leucine arylamidase, acid phosphatase, and $\beta$-galactosidase and moderate esterase (C4) activities, while it was the only strain that lacked alkaline phosphatase activity. Finally, none of the LAB strains tested during this study showed trypsin or $\alpha$-mannosidase or $\alpha$-fucosidase activities (Table 5). 
Table 5. Enzymatic activity reactions determined by the API ZYM method of the single or multiple enterocin-producing Enterococcus Greek cheese isolates ${ }^{1}$.

\begin{tabular}{|c|c|c|c|c|c|c|c|c|c|c|c|c|}
\hline \multirow[b]{2}{*}{ Enzyme Assayed for } & \multicolumn{4}{|c|}{ Control Starter or Adjunct LAB Strains ${ }^{2}$} & \multicolumn{5}{|c|}{ Ent+ E. faecium Isolates } & \multicolumn{3}{|c|}{ Ent+ E. durans Isolates } \\
\hline & $\begin{array}{c}\text { S. } \\
\text { thermophilus } \\
\text { ST1 }\end{array}$ & $\begin{array}{c}\text { Lc. lactis } \\
\text { M78 }\end{array}$ & $\begin{array}{c}\text { Lb. } \\
\text { plantarum } \\
\text { H25 }\end{array}$ & $\begin{array}{l}\text { E. faecium } \\
\text { KE85 Ent- }\end{array}$ & $\begin{array}{l}\text { KE64 } \\
\text { KE67 }\end{array}$ & KE77 & KE82 & KE118 & GL31 & KE96 & KE100 & KE108 \\
\hline Alkaline phosphatase & - & 5 & 5 & 3 & 2 & 4 & 3 & 3 & 3 & 3 & 3 & 3 \\
\hline Esterase (C 4) & $2-3$ & 3 & 3 & 4 & 3 & 3 & 4 & 3 & 3 & 3 & 4 & 3 \\
\hline Esterase Lipase (C 8) & - & 4 & 3 & 3 & 3 & 3 & 4 & 3 & 4 & 4 & 4 & 4 \\
\hline Lipase (C 14) & - & - & 2 & - & - & - & - & - & - & - & - & - \\
\hline Leucine arylamidase & 5 & 5 & 5 & 3 & 3 & 4 & 5 & 3 & 4 & 5 & 5 & 4 \\
\hline Cystine arylamidase & 2 & 4 & 5 & - & 3 & 3 & 4 & 4 & 4 & 4 & 4 & 4 \\
\hline Trypsin & - & - & - & - & - & - & - & - & - & - & - & - \\
\hline$\alpha$-chymotrypsin & - & 3 & - & 2 & $1-2$ & 2 & 4 & - & 1 & - & - & - \\
\hline Acid phosphatase & $3-4$ & 5 & 5 & - & 4 & 4 & 5 & 5 & 5 & 5 & 5 & 5 \\
\hline $\begin{array}{l}\text { Naphthol-AS-BI- } \\
\text { phosphohydrolase }\end{array}$ & 2 & 5 & 4 & - & 3 & 3 & 3 & 4 & 3 & 3 & 3 & 3 \\
\hline$\alpha$-galactosidase & - & - & 5 & - & - & 2 & - & - & - & - & - & - \\
\hline$\beta$-galactosidase & 4 & - & 5 & - & $1-2$ & - & - & - & - & - & - & - \\
\hline$\beta$-glucuronidase & - & - & $2-3$ & - & - & - & - & - & - & - & - & - \\
\hline$\beta$-glucosidase & - & - & 4 & - & - & - & - & - & - & - & - & - \\
\hline $\begin{array}{c}\mathrm{N} \text {-acetyl- } \beta- \\
\text { glucosaminidase }\end{array}$ & - & - & 5 & - & - & - & - & - & - & - & - & - \\
\hline$\alpha$-mannosidase & - & - & - & - & - & - & - & - & - & - & - & - \\
\hline$\alpha$-fucosidase & - & - & - & - & - & - & - & - & - & - & - & - \\
\hline
\end{tabular}

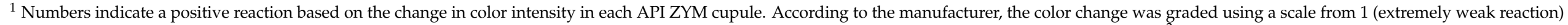

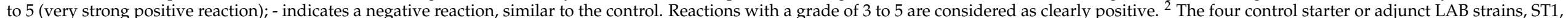

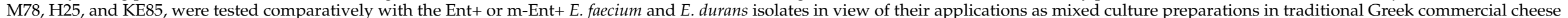
productions. 


\section{Discussion}

The lack of $\beta$-hemolytic activity and the absence of six common virulence genes and the two vancomycin resistance genes, $\operatorname{van} \mathrm{A}$ and $\operatorname{van} \mathrm{B}$ (Table 2), from the genome of all nine autochthonous, Ent+ or m-Ent+, cheese isolates of E. faecium and E. durans, were the most important and encouraging results of this study regarding their safe use as adjunct cultures in traditional Greek dairy products. Particularly for E. faecium, the absence of three virulence markers, the IS16, esp, and hyl-like genes, associated with clinical strains of the species should be a prerequisite for strains to be considered safe for use as feed additives in animal nutrition by the EFSA [30]. This requirement is logically extended to E. faecium strains intended for use in foods. Additionally, vancomycin resistance, depicted by the single or combined possession of several van genes, is one of the most common virulent traits in clinical enterococci, particularly in E. faecium strain genotypes associated with nosocomial infections [11,12]. Unfortunately, since 2000, the isolation of vancomycinresistant E. faecium strains from food processing environments and products, including traditional cheeses, has increased globally $[1,8,13]$. Particularly in the Mediterranean area, one of the first alarming screening studies was conducted by Giraffa et al. [38]: $25 \%$ of 102 Enterococcus isolates from industrial and artisan Italian cheeses were found to be resistant to both vancomycin and teicoplanin. Most of them belonged to E. feacium, harbored van A, and showed a high level of vancomycin resistance (MIC 128-512 $\mu \mathrm{g} / \mathrm{mL}$ ). However, fortunately, a considerable number of later studies showed that the incidence of virulence factors in food (cheese) isolates of $E$. faecium is strain specific, and, overall, much fewer strains within an isolated food group, most of which belonged to E. faecalis, harbored the IS16, esp A, hyl-like, and/or the $a g g$, ace, and gelE genes [16,20,39-44]. In specific, Ben Omar et al. [42] reported no detection of virulence traits (hemolysin, gelatinase, or DNAse activities) and no possession of virulence genes, including $c y l \mathrm{~L}$, ace, asaI, esp , and $\operatorname{van} \mathrm{A} / \operatorname{van} \mathrm{B}$, amongst 50 selected Enterococcus strains from Spanish dairy, meat, and vegetable foods, while only one E. faecium strain was resistant to vancomycin and teicoplanin. Limited occurrence of virulence, vancomycin, and other antibiotic resistance genes were also found in E. faecium isolates from equipment surfaces, raw materials, and traditional cheeses in Italy and Portugal [41], home-made white brine Bulgarian cheeses [43], and during traditional Portuguese Terrincho cheese making [44]. Gaglio et al. [41] specified three strains from E. faecium, E. durans, and E. casseliflavus, respectively, isolated from stretched Italian cheeses that were totally free of virulence determinants, as were all Ent+ or m-Ent+ E. faecium and E. durans Greek cheese isolates of this study.

Moreover, in general agreement with our previous findings regarding the natural presence of $\beta$-hemolytic and cyl-positive E. faecalis strains in Galotyri PDO cheeses [6], the cytolysin gene/s and some of the virulence genes in Table 2 were detected in several E. faecalis cheese isolates $[16,19,20]$. However, these genes were absent in E. faecium isolates from Italian Valtelina Casera raw milk cheese [16] or they were sporadically detected in E. faecium and E. durans isolates from Istrian raw milk cheeses [20], other Serbian or Croatian cheeses [17,45], and Egyptian fresh raw milk cheeses [46]. Similarly, few Enterococcus isolates, most likely E. faecalis rather than E. faecium, from raw donkey milk in Cyprus, harbored the gelE, asa1, ace, and esp genes, but none of the van $\mathrm{A}$ or van $\mathrm{B}$ genes [47]. No Enterococcus isolate from Pico cheese presented van $\mathrm{A}$ or van $\mathrm{B}$ genes, while $93 \%$ were $\alpha$-hemolytic [19], in general agreement with our present findings (Table 3).

To summarize the Enterococcus safety part of this study, selection for testing of the IS16, esp A, hyl, agg, ace, and gelE virulence genes plus the van A and van $\mathrm{B}$ genes (Table 2) was based on the EFSA guidance [30] but also on a preceding literature survey, including all previous dairy food studies by other workers discussed above. Absence of all eight genes tested (Table 2) and of the cytolysin gene from any Enterococcus sp., including E. faecium or E. durans, candidate strain for use as adjunct culture in (dairy) foods is required. However, this requirement appears not to apply regarding the presence of the esp gene (previously correlated with pathogenesis) in food (dairy) Enterococcus strains: this gene mostly associates with the genes involved in adhesion properties and biofilm 
formation, implicating their beneficial probiotic role in gut colonization as probiotics, rather than with the virulence traits [45,47]. Accordingly, E. faecium 894 from artisanal goatskin casing Turkish Tulum cheese was shown to be a probiotic candidate strain for further in vivo studies, although it harbored asa1, gelE, and cylA genes [48]. Notably, the cytolysin gene was also detected in our m-Ent+ E. durans KE108 strain genotype (Table 1).

Nevertheless, compared to E. faecium, E. durans is less studied regarding its biotechnological and safe use in cheese and other dairy products. However, E. durans was the most prevalent beneficial species in several commercial batches of naturally fermented and ripened Greek Graviera cheeses [4] and in many Western Balkan artisan cheeses studied more recently [17]. Thus, 10 completely harmless and biotechnologically promising $E$. durans strains from the above Western Balkan cheeses were selected for use as cheese adjunct cultures [17]. E. durans LAB18s, another safe strain from Brazilian Minas Frescal cheese, without virulence or vancomycin resistance genes and susceptible to erythromycin, tetracycline, vancomycin, gentamicin, and penicillin, has been described [49].

The in vitro phenotypic susceptibility of cheese isolates of the E. faecium/durans genomic group to different antibiotic groups is also a strongly strain-specific trait that displays major variations from country to country, from the raw materials to the final cheese product, and between cheese varieties and research studies. Overall, apart from their susceptibility to vancomycin discussed above, most dairy isolates of E. faecium are also generally susceptible to ampicillin, chloramphenicol, gentamicin, penicillin, and tetracycline $[39,43,44,47,48]$. However, many E. faecium strains that display resistance to gentamicin, penicillin, and mainly tetracycline and present the respective antibiotic resistance genes occur in traditional cheeses [20,41,46]. Conversely, most E. faecium isolates from (dairy) foods display an increased resistance or intermediate susceptibility to erythromycin and ciprofloxacin $[16,17,20,39,41,47]$. In this study, none of our antagonistic E. faecium isolates was extremely resistant to the above antibiotics, as the clinical 315VR strain was. However, most of them showed a moderate resistance or intermediate susceptibility to erythromycin and ciprofloxacin, while three were resistant to penicillin and E. faecium KE85 was distinctly resistant to tetracycline (Table 3). E. faecium isolates with multi-resistance profiles, i.e., from 2 to 4 of the above antibiotics, were also frequent in cheese studies by others [17], while E. durans isolates presented an overall higher antibiotic susceptibility than their E. faecium co-isolates [17,49], as they also did in Table 3.

The strong in vitro tyrosine decarboxylase activity and the very weak, if any, histidine decarboxylase activity of all Greek cheese isolates of the E. faecium/durans group (Table 4) are in complete agreement with the data of many relevant previous studies. Bover-Cid and Holzapfel [36] screened 10 E. faecium, 1 E. durans, and 15 E. faecalis for BA formation in improved broth, followed by HPLC quantification, and found tyramine levels from 379 to $4986 \mathrm{mg} / \mathrm{L}$, depending on the strain rather than the species, whereas no strain formed histamine. Later, Ladero et al. [50] suggested that tyramine biosynthesis is actually a species-level characteristic trait of E. faecium, E. durans, and E. faecalis, which we also confirmed in this study. Similarly, levels of tyramine ranged from 99.1 to $3664.7 \mathrm{mg} / \mathrm{L}$ within eight strains of the E. faecium/durans group cultured in modified BA broth media by Espinosa-Pesqueira et al. [51]. Notably, both tyramine and histamine were not detected in the cultures of four strains of Lb. plantarum, one Lc. Lactis, and one S. thermophilus grown in MP decarboxylase broth by Coton et al. [52], which corroborates our findings regarding the control strains H25, M78, and ST1, respectively (Table 4). Nevertheless, biogenic amines, particularly tyramine, histamine, putrescine, and cadaverine, are naturally formed by decarboxylating bacteria, including enterococci, and yeasts in all dairy products. However, their levels readily increase $>200 \mathrm{mg} / \mathrm{Kg}$ in mold-ripened and hard/semi-hard ripened raw milk cheeses, where they may occasionally increase $>1000 \mathrm{mg} / \mathrm{Kg}$ to cause toxicological concerns [15]. On the contrary, BAs remain undetected or below $60 \mathrm{mg} / \mathrm{Kg}$ in milk, fresh cheese curds, whey, and unripened cheeses from pasteurized milk [15]. Pilot-scale Galotyri and Graviera cheese trials are in progress to evaluate the ability of selected Ent+ E. faecium/durans adjuncts to form tyramine in situ. 
Finally, the hydrolysis (API-ZYM) profiles from whole cells of the nine Ent+ or m-Ent+ E. faecium and E. durans isolates from Graviera and Galotyri cheeses (Table 5) were similar to the profiles of E. faecium isolates from Turkish Beyaz raw ewe milk cheese [53]. Particularly, $\alpha$-galactosidase activity has been reported as a key differentiating enzymatic reaction between E. durans (negative; as strains KE96 = KE100 and KE108 were in Table 5) and its closely-related species E. hirae (positive) [54]. Domingos-Lopes et al. [19] concluded that selected LAB strains with $\beta$-galactosidase, esterase-lipase, and aminopeptidase activities, with moderate proteolytic activity and high diacetyl production, lacking in $\beta$-glucoronidase and $\beta$-glucosidase activities, have the potential to be used as adjunct cultures in traditional cheese productions. All Ent+ or m-Ent+ E. faecium and E. durans Greek cheese isolates of this study fulfill the above technological criteria, except $\beta$-galactosidase, in vitro (Table 5). Further studies are needed to evaluate their actual biochemical capabilities as adjunct strains in situ during traditional Greek cheese making trials. So far, only the m-Ent+ E. faecium KE82 strain genotype has successfully been applied as a novel antilisterial adjunct culture in experimental Graviera and Galotyri PDO cheeses produced under real factory-scale or pilot-scale manufacturing conditions $[55,56]$.

\section{Conclusions}

In conclusion, apart from the m-Ent+ (A-B-P) E. faecium KE82 strain genotype, the mEnt+ (A-B-P) E. faecium KE118, the entA+ E. faecium KE64 and GL31, and the entP+ E. durans KE100 strain genotypes are also safe for use as cheese adjuncts. All these strain genotypes were shown to be free of risk (virulence gene) determinants and susceptible to vancomycin and most of the other seven antibiotics tested. Notably, the E. durans KE100 strain showed stronger aminopeptidase activities (Table 5 ) and stronger acetoin forming capacity than all tested E. faecium strains in vitro [6]. Conversely, the m-Ent+ (entP-bac31-cyl) E. durans KE108 requires further safety validations because it harbors the cytolysin gene [21], probably acquired by horizontal gene transfer from a co-existing E. faecalis strain $[6,14]$ in raw milk, the plant environment, or during cooked hard cheese processing [4,5]. Based on the practical experience we have gained since 2015 regarding the routine use of the NisA+ Lc. lactis subsp. cremoris M78 in commercial Graviera cheese production at the Pappas Bros. traditional dairy (Skarfi E.P.E., Filippiada, Epirus, Greece), it is feasible to circulate autochthonous Enterococcus and other wild LAB strains as fresh craft-made adjunct starters by culturing and preserving them in sterile skim milk in domestic freezers $\left(-20\right.$ to $\left.-30^{\circ} \mathrm{C}\right)$ available in small Greek dairies. Factory-scale cheese-making trials are on the way to evaluating the overall biotechnological performance of the present Ent+ or m-Ent+ strains of the E. faecium/durans group as adjunct cultures.

Supplementary Materials: The following are available online at https:/ /www.mdpi.com/article/ 10.3390/microorganisms9040777/s1, Figure S1: (A) Agarose gel electrophoresis of multiplex PCR products of van A/van B in the clinical strain 315VR used as positive control. M: $\lambda$ DNA/HindIII (HT Biotechnologies); 1: $\operatorname{van} \mathrm{A} ; 2: \operatorname{van} \mathrm{A} / \operatorname{van} \mathrm{B}, 3: \mathrm{ddH} 2 \mathrm{O}$ as negative control; (B) Agarose gel electrophoresis of multiplex PCR products of $\operatorname{van} \mathrm{A} / \operatorname{van} \mathrm{B}$ in the studied control $\mathrm{LAB}$ and the E. faecium and E. durans strains. M: $\lambda$ DNA/HindIII (HT Biotechnologies). Figure S2: (A) Agarose gel electrophoresis of PCR products for virulence genes gelE and ace in E. faecalis ATCC ${ }^{\circledR} 29212^{\mathrm{TM}}$, reference strain. M: $\lambda$ DNA/HindIII (HT Biotechnologies); Agarose gel electrophoresis of PCR products for virulence genes: (B) gelE and C) ace in the studied control LAB and the E. faecium and E. durans strains. M: $\lambda$ DNA/HindIII (HT Biotechnologies). Figure S3: Agarose gel electrophoresis of PCR products for virulence genes: (A) IS16, (B) hyl, (C) agg and (D) espA in the studied control LAB and the E. faecium and E. durans strains. M: $\lambda$ DNA/HindIII (HT Biotechnologies).

Author Contributions: Conceptualization, A.-I.K. and J.S.; methodology, C.T., S.A., C.F., E.V., L.B., and J.S.; validation, L.B., S.A., and E.V.; formal analysis, C.T., S.A., N.S., E.V., and J.S.; investigation, J.S.; data curation, J.S.; writing-original draft preparation, C.T., S.A., and J.S.; writing—review and editing, L.B. and J.S.; funding acquisition, A.-I.K. and J.S. All authors have read and agreed to the published version of the manuscript. 
Funding: Funding of this study was provided by the European Union and Greek national funds through the EPAnEK 2014-2020 Operational Program Competitiveness, Entrepreneurship, and Innovation under RESEARCH-CREATE-INNOVATE (project T1EDK-00968; BIO TRUST).

Institutional Review Board Statement: Not applicable.

Informed Consent Statement: Not applicable.

Data Availability Statement: The data presented in this study, as well as the bacterial strains used, are available on request from the corresponding author. The 16S rRNA gene sequences of six indigenous Greek cheese isolates are deposited in GenBank; refer to Accession numbers in Table 1.

Conflicts of Interest: The authors declare no conflict of interest.

\section{References}

1. Moreno, M.F.; Sarantinopoulos, P.; Tsakalidou, E.; De Vuyst, L. The role and application of enterococci in food and health. Int. J. Food Microbiol. 2006, 106, 1-24. [CrossRef]

2. Giraffa, G. Functionality of enterococci in dairy products. Int. J. Food Microbiol. 2003, 88, 215-222. [CrossRef]

3. Litopoulou-Tzanetaki, E.; Tzanetakis, N. Microbiological characteristics of Greek traditional cheeses. Small Rumin. Res. 2011, 101, 17-32. [CrossRef]

4. Vandera, E.; Kakouri, A.; Koukkou, A.I.; Samelis, J. Major ecological shifts within the dominant nonstarter lactic acid bacteria in mature Greek Graviera cheese as affected by the starter culture type. Int. J. Food Microbiol. 2019, 290, 15-26. [CrossRef] [PubMed]

5. Samelis, J.; Lianou, A.; Kakouri, A.; Delbès, C.; Rogelj, I.; Bogovič-Matijašić, B.; Montel, M.-C. Changes in the Microbial Composition of Raw Milk Induced by Thermization Treatments Applied Prior to Traditional Greek Hard Cheese Processing. J. Food Prot. 2009, 72, 783-790. [CrossRef] [PubMed]

6. Vandera, E.; Parapouli, M.; Kakouri, A.; Koukkou, A.-I.; Hatziloukas, E.; Samelis, J. Structural enterocin gene profiles and mode of antilisterial activity in synthetic liquid media and skim milk of autochthonous Enterococcus spp. isolates from artisan Greek Graviera and Galotyri cheeses. Food Microbiol. 2020, 86, 103335. [CrossRef] [PubMed]

7. Samelis, J.; Kakouri, A. Major technological differences between an industrial-type and five artisan-type Greek PDO Galotyri market cheeses as revealed by great variations in their lactic acid microbiota. AIMS Agric. Food 2019, 4, 685-710. [CrossRef]

8. Graham, K.; Stack, H.; Rea, R. Safety, beneficial and technological properties of enterococci for use in functional food applicationsA review. Crit. Rev. Food Sci. Nutr. 2020, 60, 3836-3861. [CrossRef] [PubMed]

9. Sarantinopoulos, P.; Andrighetto, C.; Georgalaki, M.D.; Rea, M.C.; Lombardi, A.; Cogan, T.M.; Kalantzopoulos, G.; Tsakalidou, E. Biochemical properties of enterococci relevant to their technological performance. Int. Dairy J. 2001, 11, 621-647. [CrossRef]

10. Khan, H.; Flint, S.; Yu, P.-L. Enterocins in food preservation. Int. J. Food Microbiol. 2010, 141, 1-10. [CrossRef]

11. Franz, C.M.; Huch, M.; Abriouel, H.; Holzapfel, W.; Gálvez, A. Enterococci as probiotics and their implications in food safety. Int. J. Food Microbiol. 2011, 151, 125-140. [CrossRef] [PubMed]

12. Hanchi, H.; Mottawea, W.; Sebei, K.; Hammami, R. The Genus Enterococcus: Between Probiotic Potential and Safety ConcernsAn Update. Front. Microbiol. 2018, 9, 1791. [CrossRef] [PubMed]

13. Braiek, B.O.; Smaoui, S. Enterococci: Between emerging pathogens and potential probiotics. BioMed. Res. Int. 2019, 5938210. [CrossRef]

14. Eaton, T.J.; Gasson, M.J. Molecular screening of Enterococcus virulence determinants and potential for genetic exchange be-tween food and medical isolates. Appl. Environ. Microbiol. 2001, 67, 1628-1635. [CrossRef]

15. Linares, D.M.; Martín, M.C.; Ladero, V.; Alvarez, M.A.; Fernández, M. Biogenic Amines in Dairy Products. Crit. Rev. Food Sci. Nutr. 2011, 51, 691-703. [CrossRef]

16. Morandi, S.; Silvetti, T.; Lopez, J.M.; Brasca, M. Antimicrobial Activity, Antibiotic Resistance and the Safety of Lactic Acid Bacteria in Raw Milk Valtellina Casera Cheese. J. Food Saf. 2014, 35, 193-205. [CrossRef]

17. Terzić-Vidojević, A.; Veljović, K.; Begović, J.; Filipić, B.; Popović, D.; Tolinački, M.; Miljković, M.; Kojić, M.; Golić, N. Diversity and antibiotic susceptibility of autochthonous dairy enterococci isolates: Are they safe candidates for autochthonous starter cultures? Front. Microbiol. 2015, 6, 954. [CrossRef] [PubMed]

18. El-Ghaish, S.; Hadji-Sfaxi, I.; Ahmadova, A.; Choiset, Y.; Rabesona, H.; Sitohy, M.; Haertlé, T.; Chobert, J. Characterization of two safe Enterococcus strains producing enterocins isolated from Egyptian dairy products. Benef. Microbes 2011, 2, 15-27. [CrossRef]

19. Domingos-Lopes, M.F.P.; Stanton, C.; Ross, P.R.; Dapkevicius, M.L.E.; Silva, C.C.G. Genetic diversity, safety and technological characterization of lactic acid bacteria isolated from artisanal Pico cheese. Food Microbiol. 2017, 63, 178-190. [CrossRef] [PubMed]

20. Fuka, M.M.; Maksimovic, A.Z.; Tanuwidjaja, I.; Hulak, N.; Schloter, M. Characterization of Enterococcal Community Isolated from an Artisan Istrian Raw Milk Cheese: Biotechnological and Safety Aspects. Food Technol. Biotechnol. 2017, 55, 368-380. [CrossRef]

21. Cox, C.R.; Coburn, P.S.; Gilmore, M.S. Enterococcal cytolysin: A novel two component peptide system that serves as a bacterial defense against eukaryotic and prokaryotic cells. Curr. Prot. Pept. Sci. 2005, 6, 77-84. [CrossRef] [PubMed]

22. Kim, E.B.; Kopit, L.M.; Harris, L.J.; Marco, M.L. Draft Genome Sequence of the Quality Control Strain Enterococcus faecalis ATCC 29212. J. Bacteriol. 2012, 194, 6006-6007. [CrossRef] 
23. Yildiz, O.; Turkyilmaz, S. Investigation of virulence genes of Enterococcus faecalis strains isolated from mastitic bovine milk. Israel J. Vet. Med. 2015, 70, 15-21.

24. Asimakoula, S.; Giaka, K.; Fanitsios, C.; Kakouri, A.; Vandera, E.; Samelis, J.; Koukkou, A.I. Monitoring growth compatibility and bacteriocin gene transcription of adjunct and starter lactic acid bacterial strains in milk. J. Food Prot. 2021, 84, 509-520. [CrossRef]

25. Hudzicki, J. Kirby-Bauer Disk Diffusion Susceptibility Test Protocol Author Information; 2012 American Society for Micro-biology, 1-13 December 2009. Available online: https:/ / www.asm.org/Protocols/Kirby-Bauer-Disk-Diffusion-Susceptibility-Test-Pro (accessed on 29 August 2018).

26. CLSI. Performance Standards for Antimicrobial Susceptibility Testing, 26th ed.; CLSI Supplement M100S; Clinical and Laboratory Standards Insitute: Wayne, PA, USA, 2016.

27. Parapouli, M.; Delbès-Paus, C.; Kakouri, A.; Koukkou, A.-I.; Montel, M.-C.; Samelis, J. Characterization of a Wild, Novel Nisin A-Producing Lactococcus Strain with an L. lactis subsp.cremorisGenotype and an L. lactis subsp.lactisPhenotype, Isolated from Greek Raw Milk. Appl. Environ. Microbiol. 2013, 79, 3476-3484. [CrossRef] [PubMed]

28. William, S.; Helene, F.; Copeland, A. Bacterial DNA Isolation CTAB Protocol Bacterial Genomic DNA Isolation Using CTAB; Doe Joint Genome Institute: Walnut Creek, CA, USA, 2012; p. 4.

29. Sambrook, J.; Russell, D.W. Molecular Cloning: A Laboratory Manual, 3rd ed.; Cold Spring Harbor Laboratory Press: New York, NY, USA, 2001.

30. European Food Safety Authority (EFSA). Guidance on the safety assessment of Enterococcus faecium in animal nutrition. EFSA J. 2012, 10, 2682. [CrossRef]

31. Petrich, A.; Luinstra, K.; Groves, D.; Chernesky, M.; Mahony, J. Direct detection of vanA and vanB genes in clinical specimens for rapid identification of vancomycin resistant enterococci (VRE) using multiplex PCR. Mol. Cell. Probes 1999, 13, $275-281$. [CrossRef]

32. Espeche, M.C.; Pellegrino, M.; Frola, I.; Larriestra, A.; Bogni, C.; Nader-Macías, M.F. Lactic acid bacteria from raw milk as potentially beneficial strains to prevent bovine mastitis. Anaerobe 2012, 18, 103-109. [CrossRef]

33. Al-Talib, H.; Zuraina, N.; Kamarudin, B.; Yean, C.Y. Genotypic variations of virulent genes in Enterococcus faecium and Enter-ococcus faecalis isolated from three hospitals in Malaysia. Adv. Clin. Experim. Med. 2015, 24, 121-127. [CrossRef] [PubMed]

34. Werner, G.; Witte, W.; Klare, I.; van Schaik, W.; Fleige, C.; Geringer, U. IS element IS16 as a molecular screening tool to identify hospital-associated strains of Enterococcus faecium. BMC Inf. Dis. 2011, 11, 80. [CrossRef]

35. Vankerckhoven, V.; Van Autgaerden, T.; Vael, C.; Lammens, C.; Chapelle, S.; Rossi, R.; Jabes, D.; Goossens, H. Development of a multiplex PCR for the detection of asa1, gelE, cylA, esp and hyl genes in enterococci and survey for virulence determinants among European hospital isolates of Enterococcus faecium. J. Clin. Microbiol. 2004, 42, 4473-4479. [CrossRef]

36. Bover-Cid, S.; Holzapfel, W.H. Improved screening procedure for biogenic amine production by lactic acid bacteria. Int. J. Food Microbiol. 1999, 53, 33-41. [CrossRef]

37. Eerola, S.; Hinkkanen, R.; Lindfors, E.; Hirvi, T. Liquid chromatographic determination of biogenic amines in dry sausages. J. AOAC Int. 1993, 76, 575-580. [CrossRef]

38. Giraffa, G.; Olivari, A.; Neviani, E. Isolation of vancomycin-resistant Enterococcus faecium from Italian cheeses. Food Microbiol. 2000, 17, 671-677. [CrossRef]

39. Franz, C.M.A.P.; Muscholl-Silberhorn, A.B.; Yousif, N.M.K.; Vancanneyt, M.; Swings, J.; Holzapfel, W.H. Incidence of viru-lence factors and antibiotic resistance among enterococci isolated from food. Appl. Environ. Microbiol. 2001, 67, 4385-4389. [CrossRef] [PubMed]

40. Vancanneyt, M.; Lombardi, A.; Andrighetto, C.; Knijff, E.; Torriani, S.; Björkroth, K.J.; Franz, C.M.A.P.; Moreno, M.R.F.; Revets, H.; De Vuyst, L.; et al. Intraspecies Genomic Groups in Enterococcus faecium and Their Correlation with Origin and Pathogenicity. Appl. Environ. Microbiol. 2002, 68, 1381-1391. [CrossRef] [PubMed]

41. Gaglio, R.; Couto, N.; Marques, C.; Lopes, M.F.S.; Moschetti, G.; Pomba, C.; Settanni, L. Evaluation of antimicrobial resistance and virulence of enterococci from equipment surfaces, raw materials and traditional cheeses. Int. J. Food Microbiol. 2016, 236, 107-114. [CrossRef] [PubMed]

42. Omar, N.B.; Castro, A.; Lucas, R.; Abriouel, H.; Yousif, N.M.; Franz, C.M.; Holzapfel, W.H.; Rubén, P.-P.; Martínez-Canãmero, M.; Gálvez, A. Functional and Safety Aspects of Enterococci Isolated from Different Spanish Foods. Syst. Appl. Microbiol. 2004, 27, 118-130. [CrossRef]

43. Favaro, L.; Basaglia, M.; Casella, S.; Hue, I.; Dousset, X.; Franco, B.D.G.D.M.; Todorov, S.D. Bacteriocinogenic potential and safety evaluation of non-starter Enterococcus faecium strains isolated from home made white brine cheese. Food Microbiol. 2014, 38, 228-239. [CrossRef]

44. Pimentel, L.L.; Semedo, T.; Tenreiro, R.; Crespo, M.T.B.; Pintado, M.M.E.; Malcata, F.X. Assessment of Safety of Enterococci Isolated throughout Traditional Terrincho Cheesemaking: Virulence Factors and Antibiotic Susceptibility. J. Food Prot. 2007, 70 , 2161-2167. [CrossRef]

45. Popović, N.; Dinić, M.; Tolinački, M.; Mihajlović, S.; Terzić-Vidojević, A.; Bojić, S.; Djokić, J.; Golić, N.; Veljović, K. New in-sight into biofilm formation ability, the presence of virulence genes and probiotic potential of Enterococcus sp. dairy isolates. Front. Microbiol. 2018, 9, 78. [CrossRef]

46. Hammad, A.M.; Hassan, H.A.; Shimamoto, T. Prevalence, antibiotic resistance and virulence of Enterococcus spp. in Egyptian fresh raw milk cheese. Food Control 2015, 50, 815-820. [CrossRef] 
47. Aspri, M.; Bozoudi, D.; Tsaltas, D.; Hill, C.; Papademas, P. Raw donkey milk as a source of Enterococcus diversity: Assessment of their technological properties and safety characteristics. Food Control 2017, 73, 81-90. [CrossRef]

48. Özkan, E.R.; Demirci, T.; Akin, N. In vitro assessment of probiotic and virulence potential of Enterococcus faecium strains de-rived from artisanal goatskin casing Tulum cheeses produced in central Taurus Mountains of Turkey. LWT Food Sci. Technol. 2021, 141, 110908. [CrossRef]

49. Pieniz, S.; de Moura, T.M.; Cassenego, A.P.V.; Andreazza, R.; Frazzon, A.P.G.; de Oliveira Camargo, F.A.; Brandelli, A. Evaluation of resistance genes and virulence factors in a food isolated Enterococcus durans with potential probiotic effect. Food Control 2015, 51, 49-54. [CrossRef]

50. Ladero, V.; Fernández, M.; Calles-Enríquez, M.; Sánchez-Llana, E.; Cañedo, E.; Martín, M.C.; Alvarez, M.A. Is the production of the biogenic amines tyramine and putrescine a species-level trait in enterococci? Food Microbiol. 2012, 30, 132-138. [CrossRef] [PubMed]

51. Espinosa-Pesqueira, D.; Roig-Sagués, A.X.; Hernández-Herrero, M.M. Screening method to evaluate amino ac-id-decarboxylase activity of bacteria present in Spanish artisanal ripened cheeses. Foods 2018, 7, 182. [CrossRef] [PubMed]

52. Coton, M.; Lebreton, M.; Salas, M.L.; Garnier, L.; Navarri, M.; Pawtowski, A.; Le Blay, G.; Valence, F.; Coton, E.; Mounier, J. Biogenic amine and antibiotic resistance profiles determined for lactic acid bacteria and a propionibacterium prior to use as antifungal bioprotective cultures. Int. Dairy J. 2018, 85, 21-26. [CrossRef]

53. Durlu-Ozkaya, F.; Xanthopoulos, V.; Tunail, N.; Litopoulou-Tzanetaki, E. Technologically important properties of lactic acid bacteria isolates from Beyaz cheese made from raw ewes' milk. J. Appl. Microbiol. 2001, 91, 861-870. [CrossRef] [PubMed]

54. Manero, A.; Blanch, A.R. Identification of Enterococcus spp. with a Biochemical Key. Appl. Environ. Microbiol. 1999, 65, 4425-4430. [CrossRef] [PubMed]

55. Giannou, E.; Kakouri, A.; Matijašic, B.B.; Rogelj, I.; Samelis, J. Fate of Listeria monocytogenes on fully ripened Greek Graviera cheese stored at 4,12 , or $25 \mathrm{oC}$ in air or vacuum packages: In situ PCR detection of a cocktail of bacteriocins potentially contributing to pathogen inhibition. J. Food Prot. 2009, 72, 531-538. [CrossRef] [PubMed]

56. Sameli, N.; Skandamis, P.N.; Samelis, J. Application of Enterococcus faecium KE82, an Enterocin A-B-P-Producing Strain, as an Adjunct Culture Enhances Inactivation of Listeria monocytogenes during Traditional Protected Designation of Origin Galotyri Processing. J. Food Prot. 2021, 84, 87-98. [CrossRef] [PubMed] 